\title{
Heavy Metal Uptake and Translocation by Dipterocarpus verrucosus from Sewage Sludge Contaminated Soil
}

\author{
${ }^{1}$ Keeren Sundara Rajoo, ${ }^{1,3}$ Arifin Abdu, ${ }^{2,3}$ Daljit Karam Singh, \\ ${ }^{1,3}$ Hazandy Abdul-Hamid, ${ }^{2}$ Shamshuddin Jusop and ${ }^{1}$ Wong Wan Zhen \\ ${ }^{1}$ Department of Forest Management, Faculty of Forestry, \\ ${ }^{2}$ Department of Land Management, Faculty of Agriculture, \\ ${ }^{3}$ Institute of Tropical Forestry and Forest Products, \\ Universiti Putra Malaysia, 43400 UPM Serdang, Selangor, Malaysia
}

Received 2013-05-15, Revised 2013-07-09; Accepted 2013-07-09

\begin{abstract}
Sewage sludge or biosolids is the solid waste that has been left after wastewater is treated in a domestic wastewater treatment facility. The most common way of sludge disposal is to dispose it on the land, sea or air (incineration). However, these methods are not environment-friendly, costly and time consuming that requires expertise and knowledge. An ideal way to manage sewage sludge is to use it as a soil amendment in agricultural land due to it's high organic matter and other base cations. Sewage sludge contains high levels of heavy metals such as lead, cadmium and zinc that can be harmful to both plants and the environment. Hence, these metals need to be removed before the sewage sludge is used as a soil amendment. The objective of this study was to assess the potential of Dipterocarpus verrucosus to uptake and translocate heavy metals from sewage sludge contaminated soil. The D.verrucosus seedlings were planted on six different planting media; Control (100\% soil), T1 (80\% soil and $20 \%$ sewage sludge), T2 (60\% soil and 40\% sewage sludge), T3 (40\% soil and $60 \%$ sewage sludge), T4 (20\% soil and 80\% sewage sludge) and T5 (100\% sewage sludge) for the duration of 16 weeks. The growth performance, of height of D.verrucosus was measured using diameter tape, while the basal diameter was measured using a venier caliper for every two weeks for a period of 16 weeks. The plant biomass was determined using a destructive sampling method. Plant samples were collected after harvest and soil samples were collected before and after planting. The Atomic Absorbtion Spectrophotometer (AAS) was used to determine the concentration of heavy metals in the planting media and the plant parts (leaves, stem and roots). The highest plant biomass was recorded in the T1 growth media of $20 \%$ sewage sludge and $80 \%$ soil. D.verrucosus plant was able to remove heavy metals of $\mathrm{Cd}, \mathrm{Cu}, \mathrm{Pb}, \mathrm{Fe}$ and $\mathrm{Zn}$ effectively. The highest concentration of heavy metal in the roots of the D.verrucosus plant was Fe, recorded in the T5 growth media $(1879.75 \mathrm{ppm})$. The highest accumulation of $\mathrm{Zn}(68.47 \mathrm{ppm})$ in D.verrucosus was recorded in the stem of D.verrucosus in the T5 growth media whereas the stem of the D.verrucosus in T3 recorded the highest Cd accumulation ( $2.85 \mathrm{ppm})$. The highest $\mathrm{Pb}$ uptake was recorded in the roots of D.verrucosus in T5 (37.3 ppm), while the lowest accumulation of $\mathrm{Pb}$ was noted in the stem of the D.verrucosus in Control (23.49 ppm). For Cd, the highest translocation factor (TF) (4.01) was recorded in T1. The lowest Bioconcentration Factor (BCF) for $\mathrm{Cu}$ was recorded at T5 (0.22). The highest TF for Lead was recorded in control (2.22) while the lowest was in T1 (1.64). The BCF for Zn was lowest at T3 treatment (0.16). The D.verrucosus plant was found to be suitable for taking up heavy metals from sewage sludge especially $\mathrm{Cd}, \mathrm{Zn}, \mathrm{Cu}$ and $\mathrm{Pb}$. The roots of D.verrucosus are ideal in removing and storing Fe, while the stem of the D.verrucosus plant is ideal for the uptake and accumulation of $\mathrm{Zn}$. However, more studies need to be conducted, especially in field conditions, in order to optimize the potential of the D.verrucosus plant as a phytoremediator.
\end{abstract}

Keywords: Dipterocarpus Verrucosus, Phytoremediation, Heavy Metals, Sewage Sludge, Translocation Factor, Bioconcentration FACTOR

Corresponding Author: Arifin Abdu, Department of Forest Management, Faculty of Forestry, Universiti Putra Malaysia, 43400 UPM Serdang, Selangor, Malaysia Tel: +603-89467177 Fax: +603-89432514 


\section{INTRODUCTION}

The ever increasing human population, along with rapid industrialization and urbanization has resulted in an enormous growth in the volume of wastewater produced around the world. Wastewaters have to be treated appropriately at wastewater treatment facilities, which in turn produce solid waste products known as sewage sludge. Due to the increasing amount of wastewater needed to be treated, the amount of sewage sludge produced is constantly increasing, making proper disposal of sewage sludge a major concern. Malaysia produces about 5 million cubic meters of sewage sludge per year. The amount has been estimated to reach 7 million cubic meters per year by 2022 (Indah Water Konsortium (IWK), 1997).

Sewage sludge, also known as biosolids, is the solid waste that has been left after wastewater is treated in a domestic wastewater treatment facility. Sludge which resulted from the wastewater treatment operation is usually in a very dilute suspension form, which typically contains 0.25 to $12 \%$ of solid (Indah Water Konsortium (IWK), 1997). In addition, sludge contains pathogens, heavy metals and toxic characteristics of the untreated wastewater. It also contains high organic matter and nutrients that are essential for plant growth. Most countries very strictly regulate the usage of sewage sludge as a soil amendment because of it potentially being harmful and dangerous to humans, animals, plants and the environment, as it might contain high levels of heavy metals, organic pollutants and pathogens (Odegaard et al., 2002).

The most common way of sludge management is to dispose it on the land, into the sea or to a certain extent in the air which is mainly a consequence of incineration (Odegaard et al., 2002). Nowadays there is an increasing environmental awareness, which is causing a switch from conventional sewage sludge disposal methods to environment-friendly methods that are very costly, time consuming and requires expertise knowledge. An ideal way for sewage sludge management is by using it as a soil amendment in agricultural land. This is because it contains high organic matter and plant nutrient (N, P, K, $\mathrm{Ca}$ and $\mathrm{Mg}$ ) that makes it suitable to be used as an organic fertilizer (Singh and Argawal, 2007). However, land disposal for a long period of time may result in the accumulation of high levels of heavy metal. Sewage sludge usually contains high amounts of lead, cadmium, nickel, chromium and copper due to its industrial origin (Raymond and Felix, 2011). Even domestic sludge may contain high amount of Zinc, Copper, Cadmium, Lead
(Raymond and Felix, 2011). This is especially true for sewage sludge in Malaysia, which has very high heavy metal content (Indah Water Konsortium (IWK), 1997). Heavy metals are dangerous pollutants because they are usually are non-degradable.

Certain heavy metals occur naturally in soil, but rarely at toxic level. Sometimes they are needed in small amounts by plants and animals. However, they become toxic when the concentration is too high since they are not metabolized and accumulates in the soft tissues. Heavy metals are chemical elements with a specific gravity that is at least 5 times the specific gravity of water (Kvesitadze et al., 2010). The heavy metals indicated in the USEPA and state regulation are trace elements that can be harmful to the environment, human, animals and plants. Hence, although sewage sludge contains essential nutrients for plants, it can also potentially be harmful to the plants due to high amounts of heavy metal such as $\mathrm{Cd}, \mathrm{Zn}, \mathrm{Fe}$ and $\mathrm{Cu}$.

Phytoremediation is a technology that uses plants to degrade, extract or remediate contaminants from soil and water (Purakayastha and Chhonkar, 2010). Phytoremediation has received special attention since the last decade as this technology does not damage soil structure and just slightly changes soil microbial content (Purakayastha and Chhonkar, 2010). The assessment of the detoxification potential of the plant is determined by the rate and depth of contaminant uptake from the soil, accumulation in the plant cell and the degree of contaminant transformation to regular cell metabolites. The best plant for a particular phytoremediation task should be selected based on multiple plants characteristic (Majid et al., 2011). The actual phytoremediation related characteristics of the candidate plants should be fast growing, have high biomass and a natural tolerance to toxic substaces such as heavy metals and salinity (Majid et al., 2011).

Some plants are able to accumulate metals without showing toxicity and make excellent phytoremediators (Bennett et al., 2003). Hyper metal accumulating plant species have been identified in at least 45 plant families and individual species which can accumulate different metals (Reeves and Baker, 2000). These families are Brassicaceae, Fabaceae, Euphorbiaceae, Asteraceae, Lamiaceae and Scrophulariaceae. There is still a lack of information on the potential of plants from the Dipterocarpus family to act as a phytoremediator for heavy metals. Therfore, a study in this area is justified.

For this study, the plant species Dipterocarpus verrucosus, was selected to determine its potential to clean up toxic heavy metals present in sewage sludge. 
D.verrucosus, known as "keruing merah" locally, is a species of tree in the family Dipterocarpaceae. It is endemic to Indonesia and Malaysia. The phytochemical part of these plants have been studied before (Muhtadi, 2008), but for such a broad family plants, the chemistry of Dipterocarpaceae is relatively less known. The initial research on D.verrucosus was mainly focused on resins such as terpenoid, sesquiterpene, triterpene and its economic value as a timber tree (Zuraida and Zain, 2011). There is a lack of research on the potential of D.verrucosus as a phytoremdiator. The objective of this study was to evaluate the ability of D.verrucosus in extracting heavy metals from sewage sludge.

\section{MATERIALS AND METHODS}

\subsection{Site Description and Planting Materials}

The study was conducted at the greenhouse of University Agriculture Park, Universiti Putra Malaysia (Serdang, Malaysia) for 16 weeks (January 2012 to April 2012). The temperature at glasshouse was $27^{\circ} \mathrm{C}$ in the morning and $35^{\circ} \mathrm{C}$ in the evening while Relative humidity in the glasshouse was $65 \%$. The seedlings of the D.verrucosus tree were germinated from cuttings of the mature stem and planted in polybags $(16.0 \times 16.0$ $\mathrm{cm})$ in the Faculty of Forestry nursery, Universiti Putra Malaysia. The growing medium for the D.verrucosus seedlings were in the proportions of, soil: organic matter: river sand in a 3:2:1 ratio. The seedlings were transplanted into suitable plastic pots $(32.0 \mathrm{~cm}$ height, $106.0 \mathrm{~cm}$ upper diameter and 69.0 lower diameter) that were filled up with the mixture of soil and sewage sludge after one month.

\subsection{Nature of Species Planted}

Dipterocarpus verrucosus, commonly known as "keruing merah", is a species of tree in the family Dipterocarpaceae. It is endemic to Indonesia (Kalimantan and Sumatra) and Malaysia. Dipterocarpaceae is the most important family of economic trees in Southeast Asia. The species of this family is one of major importance in the timber trade.

\subsection{Plant and Soil Sampling and Chemical Analysis}

There were six different levels of treatments used in this study, with four replicates for each treatment. The treaments consisted of a mixture of soil and dry sewage sludge and the control containing soil only: T0/Control
(100\% soil), T1 (80 soil and 20\% sewage sludge), T2 (60 soil and 40\% sewage sludge), T3 (40 soil and 60\% sewage sludge), T4 (20 soil and 80\% sewage sludge) and T5 (100 sewage sludge). The pots were labelled according to their compositions. The Completely Randomized Design (CRD) was used in this study. The heights, diameters and number of leaves of the Dipterocarpus verrucosus plants were measured every two weeks throughout the study period with diameter tape, while the basal diameter was measured using a venier caliper every two weeks. Soil samples were collected from each pot before and after planting, kept in a standard plastic container and air-dried before physico-chemical analyses. The AAS was used for analyzing the concentrations of selected heavy metals [Iron (Fe), Zinc ( $\mathrm{Zn})$, Cadmium (Cd), Lead (Pb) and Copper $(\mathrm{Cu})]$ in the planting medium and plant parts and aqua regia was used as the extractant. Total carbon was determined using conventional method (loss on ignition), using $5 \mathrm{~g}$ of air dried soil which was kept in an oven for $8 \mathrm{~h}$ at $550^{\circ} \mathrm{C}$.

\subsection{Plant Growth and Biomass Measurement}

The plant height and basal diameter were measured every two weeks. Plant biomass was measured separately according to leaves, stems and roots using destructive sampling method. The loss in weight upon drying is the weight originally present. The moisture content of the sample was calculated using Equation 1:

$\% \mathrm{~W}=\frac{\mathrm{A}-\mathrm{B}}{\mathrm{B}} \times 100$

Where:

$\% \mathrm{~W}=$ Percentage of moisture in the sample

A $=$ Weight of wet sample

$\mathrm{B}=$ Weight of dry sample

\subsection{Translocation Factor (TF) and Bioconcentration Factor (BCF)}

The plant's ability to accumulate metals from soils and translocate metals from roots to shoots was estimated using the translocation factor (Equation 2) and the bioconcentration factor (Equation 3):

$$
\begin{aligned}
& \mathrm{TF}=\frac{\text { Metal concentration aerial parts }}{\text { Metal concentration in roots }} \\
& \mathrm{BCF}=\frac{\text { Metal concentration in roots }}{\text { Metal concentration in soil }}
\end{aligned}
$$




\subsection{Statistical Analysis}

The analyses for growth and heavy metals in the soil, sludge and plant parts were done following the Analyses of Variance (ANOVA) technique and the mean values were adjusted using a post hoc test of Tukey's ( $\mathrm{p} \leq 0.05)$. A comparison using an Independent Student's t-test at a 5\% level was done to detect any significant differences between samples taken before planting and after harvesting. Computation and preparation of graphs were done by the use of SPSS 16.00 and Microsoft EXCEL 2003 software program.

\section{RESULTS}

\subsection{General Properties of the Growth Media}

The particle size analysis of the soil was slit clay. Table 1 show that all treatments had lower $\mathrm{pH}$ (4.23 to 5.25 ) initially and increased after harvest (4.58 to 5.27). $\mathrm{T} 2$ shows the highest change in soil $\mathrm{pH}$ (4.23 to 4.89 ). Before planting, the highest total carbon was found in T5 (15.23\%) and the lowest was in the T0, control $(0.63 \%)$. There was a direct corelation with amount of sludge used in the growth media with the total carbon of the growth media, the higher the percentage of sludge in the growth media, the higher total carbon of the growth media. After harvest, the total carbon decreased in all the treatments except in $\mathrm{T} 0$, control.

The maximum total $\mathrm{C}$ content $(5.20 \%)$ was found in T4 followed by T5 (4.57\%) with the minimum content in the control of $0.91 \%$ (Table 1 ).

\subsection{Growth Performance and Plant Biomass}

The results showed significant difference $(\mathrm{p} \leq 0.05)$ among the treatments in terms of total height, basal diameter and number of leaves. Table 2 shows that D.verrucosus planted in $\mathrm{T} 1$ showed the highest height $(67.27 \mathrm{~cm})$ which was closely followed by the T0, control $(67.16 \mathrm{~cm})$. Treatment 5 showed a conspicuous decrease after week 8 . The basal diameter showed similar pattern with total height. After week 8, the basal diameter was constant for all treatment except for T1 and T2 which increased slightly. Treatment 5 $(5.5 \mathrm{~cm})$ showed the lowest basal diameter. After 16 weeks, treatment 1 produced the highest number of leaves (33). The lowest number of leaves was recorded by $T 5$, producing only 7 . The plant stems and leaves biomass showed significant difference $(\mathrm{p} \leq 0.05)$ among the treatments after 16 weeks while roots mass have no significant differences. Treatment 2 produced the highest biomass of $51.38 \mathrm{~g}, 53.28 \mathrm{~g}$ and $57.86 \mathrm{~g}$ for roots, stem and leaves, respectively. Treatment 5 produced the lowest biomass of $23.65 \mathrm{~g}$ and $14.46 \mathrm{~g}$ for stem and leaves, respectively as shown in Table 3.

Table 1. The $\mathrm{pH}$ and total $\mathrm{C}(\%)$ content in the growth media

\begin{tabular}{lllll}
\hline & \multicolumn{2}{l}{$\mathrm{pH}$} & \multicolumn{3}{l}{ Total-C } \\
\cline { 2 - 5 } Treatment & $\mathrm{A}$ & $\mathrm{B}$ & $\mathrm{A}$ & $\mathrm{B}$ \\
\hline T0 & $4.27 \pm 0.07$ & $4.58 \pm 0.11$ & $0.63 \pm 0.07$ & $0.91 \pm 0.11$ \\
T1 & $4.29 \pm 0.14$ & $4.73 \pm 0.34$ & $1.75 \pm 0.55$ & $1.60 \pm 0.31$ \\
T2 & $4.23 \pm 0.10$ & $4.89 \pm 0.33$ & $4.09 \pm 0.68$ & $2.10 \pm 0.28$ \\
T3 & $4.75 \pm 0.16$ & $4.90 \pm 0.16$ & $6.35 \pm 0.26$ & $2.32 \pm 0.48$ \\
T4 & $4.48 \pm 0.15$ & $4.65 \pm 0.26$ & $7.65 \pm 0.44$ & $5.20 \pm 1.34$ \\
T5 & $5.25 \pm 0.37$ & $5.27 \pm 0.60$ & $15.23 \pm 1.32$ & $4.57 \pm 1.51$ \\
\hline
\end{tabular}

Note: T0-control (100\% soil), T1 (80\% soil and $20 \%$ sewage sludge), T2 (60\% soil and 40\% sewage sludge), T3 ( $40 \%$ soil and $60 \%$ sewage sludge), T4 (20\% soil and $80 \%$ sewage sludge) and T5 (100\% sewage sludge), B (before planting), A (after harvesting)

Table 2. Total height, basal diameter and number of leaves of D. verrucosus at 16 weeks after planting

\begin{tabular}{llll}
\hline Treatment & Height $(\mathrm{cm})$ & Basal diameter $(\mathrm{mm})$ & No. leaves \\
\hline T0 & 67.16 & 6.6 & 22 \\
T1 & 67.27 & 7.0 & 33 \\
T2 & 66.41 & 5.9 & 16 \\
T3 & 65.56 & 6.0 & 17 \\
T4 & 65.31 & 6.0 & 18 \\
T5 & 54.33 & 5.5 & 7 \\
\hline
\end{tabular}

Note: T0-control (100\% soil), T1 $(80 \%$ soil and $20 \%$ sewage sludge), T2 (60\% soil and 40\% sewage sludge), T3 (40\% soil and $60 \%$ sewage sludge), T4 (20\% soil and $80 \%$ sewage sludge) and T5 (100\% sewage sludge)

Table 3. Average dry weight biomass (g) for roots, stem and leaves

\begin{tabular}{llll}
\hline Treatment & Roots & Stem & Leaves \\
\hline T0 & 48.07 & 51.60 & 32.02 \\
T1 & 36.26 & 52.60 & 42.29 \\
T2 & 51.38 & 53.28 & 57.86 \\
T3 & 45.50 & 44.23 & 53.11 \\
T4 & 49.28 & 40.33 & 55.36 \\
T5 & 46.62 & 23.65 & 14.46 \\
\hline
\end{tabular}

Note: T0- control (100\% soil), T1 (80\% soil and $20 \%$ sewage sludge), T2 (60\% soil and 40\% sewage sludge), T3 (40\% soil and $60 \%$ sewage sludge), T4 $(20 \%$ soil and $80 \%$ sewage sludge) and T5 (100\% sewage sludge) 

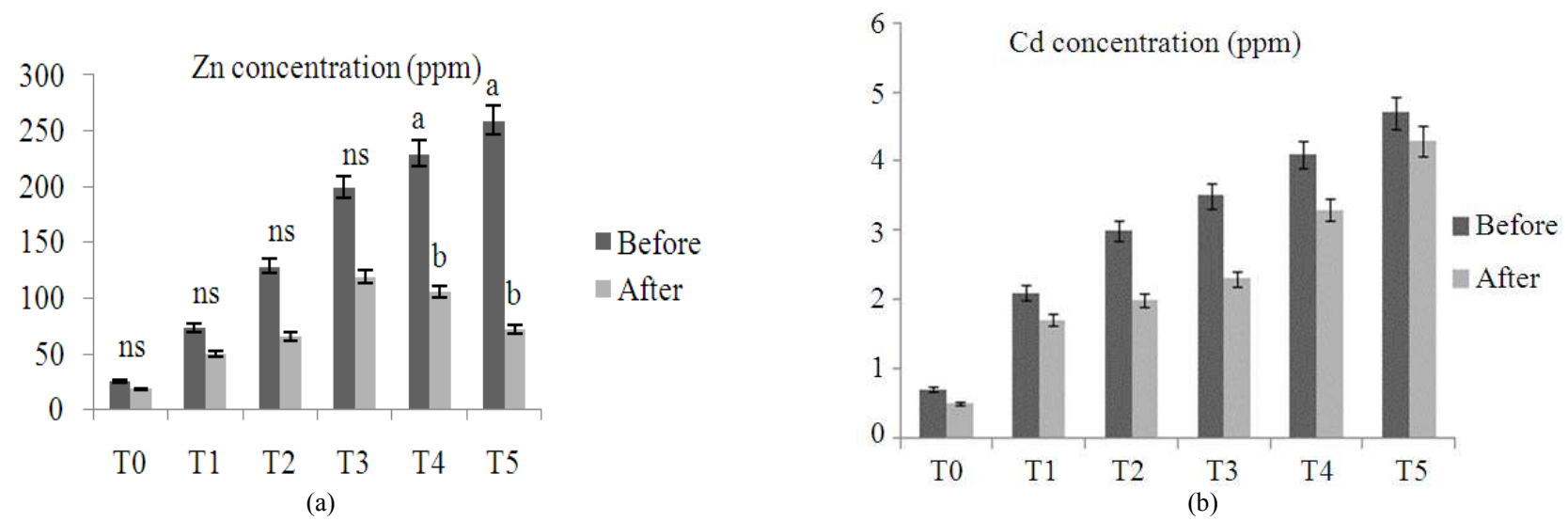

(b)
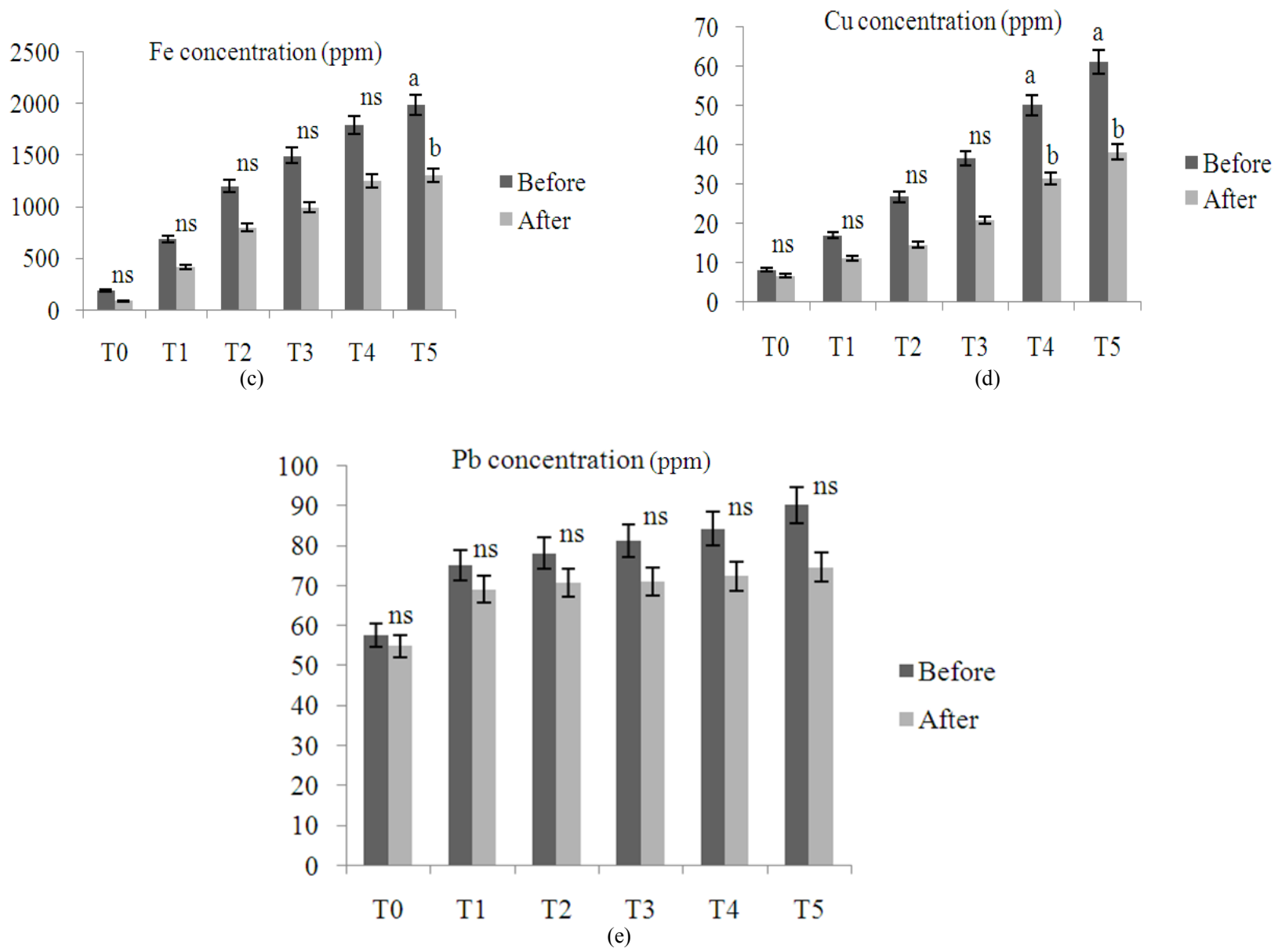

Fig. 1. The Concentrations of $\mathrm{Zn}(\mathrm{a}), \mathrm{Cd}(\mathrm{b}), \mathrm{Fe}(\mathrm{c}), \mathrm{Cu}$ (d) and $\mathrm{Pb}(\mathrm{e})$ in growth media before planting and after harvesting. * indicate significant difference between means at each treatment before planting and after harvesting according to a Student's t-test ( $\mathrm{p} \leq 0.05)$, ns indicates no significant difference. T0, (100\% soil-control); T1, ( $80 \%$ soil and $20 \%$ sewage sludge); T2, (60\% soil and $40 \%$ sewage sludge); T3, (40\% soil and 60\% sewage sludge); T4, (20\% soil and $80 \%$ sewage sludge); T5, (100\% sewage sludge) 

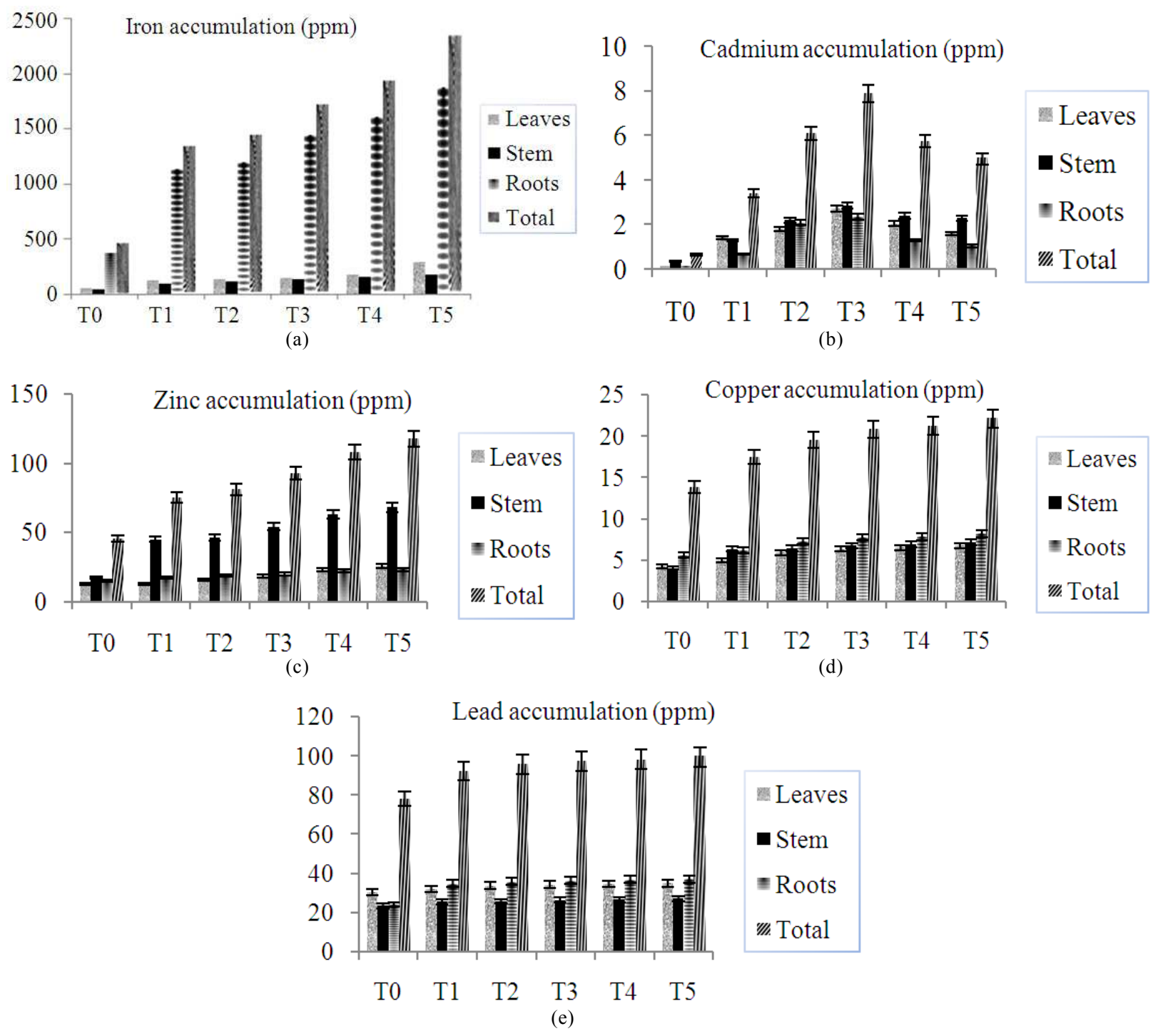

Fig. 2. Accumulation of $\mathrm{Cd}(\mathrm{a}), \mathrm{Fe}(\mathrm{b}), \mathrm{Zn}(\mathrm{c}) \mathrm{Cu}(\mathrm{d})$ and $\mathrm{Pb}(\mathrm{e})$ concentrations in the plant parts after harvesting of D.verrucosus plant as influenced by different treatments. $\mathrm{T} 0=100 \%$ soil, $\mathrm{T} 1=80 \%$ soil $+20 \%$ sewage sludge, $\mathrm{T} 2=60 \%$ soil $+40 \%$ sewage sludge, $\mathrm{T} 3=40 \%$ soil $+60 \%$ sewage sludge, $\mathrm{T} 4=20 \%$ soil $+80 \%$ sewage sludge, $\mathrm{T} 5=100 \%$ sewage sludge

\subsection{Heavy Metal Concentrations in Growth media before Planting and after Harvesting}

The concentrations of heavy metals before planting and after harvesting are shown in Fig. 1a-e. The D.verrucosus was found to be able to generally remove the heavy metals, such as $\mathrm{Zn}, \mathrm{Pb}, \mathrm{Fe}, \mathrm{Cd}$ and $\mathrm{Cu}$ especially in $\mathrm{T} 5$ where the planting medium contained $100 \%$ sewage sludge. The $\mathrm{Zn}$ content of the sewage sludge was $259.42 \mathrm{ppm}$ before planting in T5 and after harvesting, the $\mathrm{Zn}$ level decreased to 71.65 ppm (Fig. 1a). The highest decrease in Cd levels in the D.verrucosus growth media was observed in T3, where the initial level of $\mathrm{Cd}$ was $3.5 \mathrm{ppm}$ while the level of Cd after harvesting was 2.3 ppm (Fig. 1b). The level of $\mathrm{Fe}$ in the $\mathrm{T} 5$ growth media decreased after harvesting (1986.9 ppm) compared to the initial Fe level (1308.1 ppm), as shown in Fig. 1c. The highest decrease in $\mathrm{Cu}$ levels in the D.verrucosus growth media was observed in T5, where the initial level of $\mathrm{Cu}$ was $61.23 \mathrm{ppm}$ while the level of $\mathrm{Cu}$ after harvesting was $38.22 \mathrm{ppm}$ (Fig. 1d). 

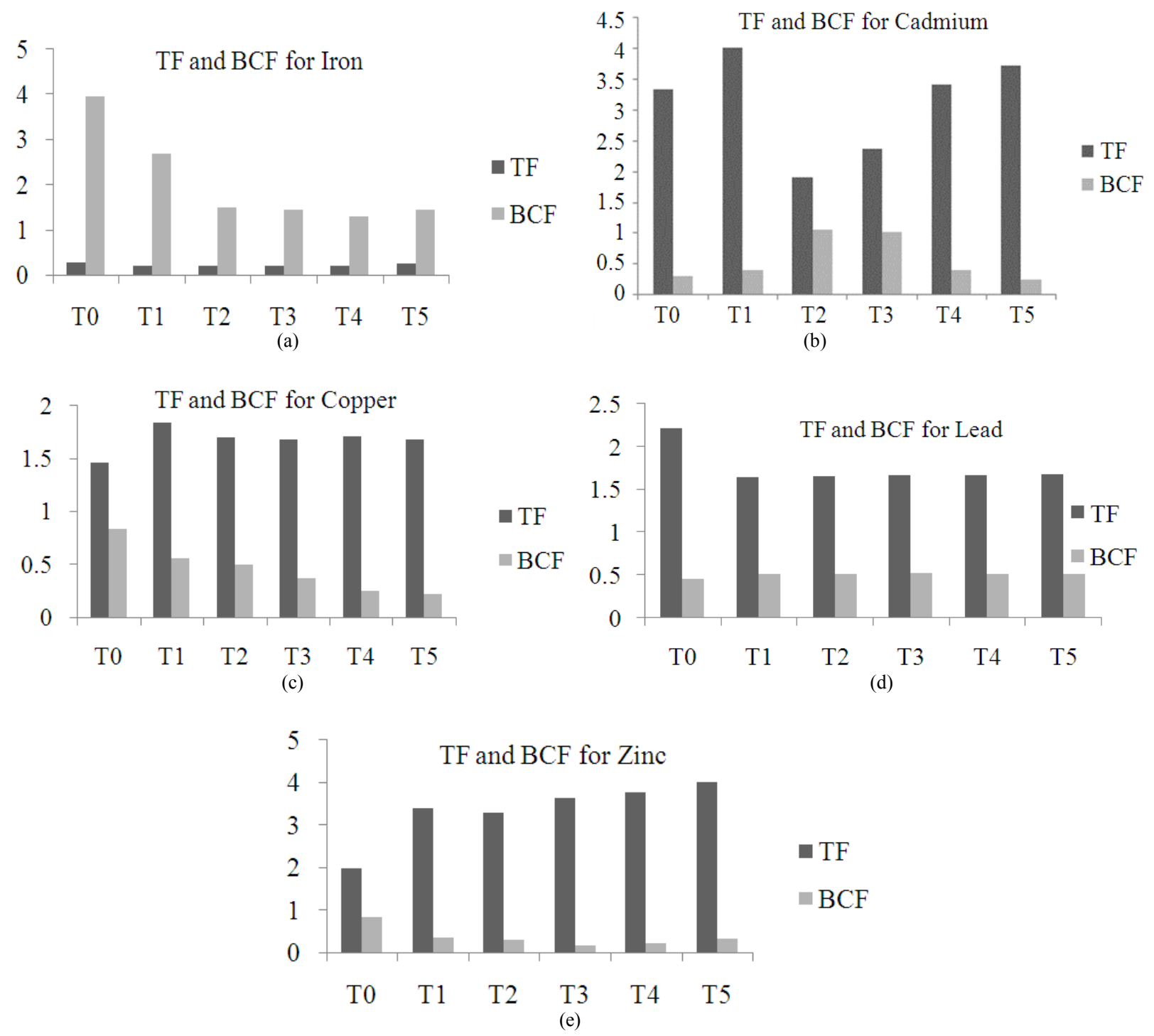

Fig. 3. Translocation factor and bioconcentration factor $\mathrm{Fe}(\mathrm{a}), \mathrm{Cd}(\mathrm{b}), \mathrm{Cu}$ (c) $\mathrm{Pb}(\mathrm{d})$ and $\mathrm{Zn}(\mathrm{e})$ of D.verrucosus plant as influenced by different treatments. $\mathrm{T} 0=100 \%$ soil, $\mathrm{T} 1=80 \%$ soil $+20 \%$ sewage sludge, $\mathrm{T} 2=60 \%$ soil $+40 \%$ sewage sludge, $\mathrm{T} 3=$ $40 \%$ soil $+60 \%$ sewage sludge, $\mathrm{T} 4=20 \%$ soil $+80 \%$ sewage sludge, $\mathrm{T} 5=100 \%$ sewage sludge

The level of $\mathrm{Pb}$ in the $\mathrm{T} 5$ growth media decreased after harvesting $(90.24 \mathrm{ppm})$; the initial Fe level 74.7 ppm, (Fig. 1e).

\subsection{Heavy Metal Concentration in Plant Parts}

The concentration of $\mathrm{Zn}, \mathrm{Cd}, \mathrm{Fe}, \mathrm{Cu}$ and $\mathrm{Cd}$ in plant parts (leaves, stem and roots) after 16 weeks of planting are shown in Fig. 2a-e. The highest Fe accumulation was observed in the roots of D.verrucosus in T5 (1879.75 ppm), as shown in Fig. 2a. Furthermore, it was found that the leaves of the D.verrucosus absorbed higher levels of Fe compared to that of stem (Fig. 2a).

Figure 2b shows that the stem of the D.verrucosus in $\mathrm{T} 3$ growth media accumulated the highest amount of $\mathrm{Cd}(2.85 \mathrm{ppm})$, while the lowest concentration was observed in the roots in control $(0.15 \mathrm{ppm})$. Figure $2 \mathrm{c}$ shows the highest $\mathrm{Zn}$ uptake was noted in the leaves at the control growth media (12.61 ppm). Figure 2d shows that the highest concentration of $\mathrm{Cu}$ was stored 
in the roots in the T5 treatment $(8.23 \mathrm{ppm})$. This was also similar for $\mathrm{Pb}$, where the highest concentration of $\mathrm{Pb}$ was found in the roots of the D.verrucosus plant in T5 (37.2 ppm), as recorded in Fig. 2e.

\subsection{Translocation Factor (TF) and Bioconcentration Factor (BCF) of Heavy Metals}

The TF and BCF of heavy metals for the D.verrucosus plant are shown in Fig. 3a-e. The TF for Iron was the lowest among the TF of all the other metals (Fig. 3a). The highest TF for Fe was recorded in Control (0.26) and the lowest was recorded for Treatment 1 (0.19). For Iron, the TF was most prominent in Control and Treatment 5. However, Fe recorded the highest BCF among the heavy metals. The highest BCF for Iron was recorded in Control (3.96), followed by Treatment 1 (2.68). For $\mathrm{Cd}$ (Fig. 3b) and Copper (Fig. 3c), the highest TF (4.01 and 1.84 for $\mathrm{Cd}$ and $\mathrm{Cu}$ respectively) was recorded in Treatment 1 . The lowest BCF for Cd and $\mathrm{Cu}$ was recorded at Treatment 5 (0.24 and 0.22 respectively). The highest TF for Lead was recorded in control (2.22) while the lowest was in treatment 1 (1.64) (Fig. 3d). The BCF for Lead was lowest at Control and Treatment 5 (0.44 and 0.49 respectively). The TF for $\mathrm{Zn}$ was most prominent in Treatment 3, Treatment 4 and Treatment 5 (3.63, 3.77 and 4.01 respectively). The highest BCF for $\mathrm{Zn}$ was observed at Control (0.84), while the lowest BCF for Zinc was recorded at Treatment 3 (0.17) (Fig. 3e).

\section{DISCUSSION}

\subsection{Changes in General Properties of Growth media}

Due to tratments, soil $\mathrm{pH}$ had increased. The highest change in soil $\mathrm{pH}$ was treatment 2 (from 4.23 to 4.89 ). This change in $\mathrm{pH}$ indicated that D.verrucosus was able to remove acidic elements such as Fe and other heavy metals from the growth media (Ghafoori et al., 2011), indicating that this plant had the potential to increase the $\mathrm{pH}$ of soils. It was found that the higher the percentage of sludge in the growth media, the higher total carbon of the growth media. This indicates that the application of sewage sludge to soil can improve the overall organic matter content of the growth media (Arifin et al., 2011). An increase in organic matter could potentially improve the overall soil fertility (Rice, 2002). Besides that, soil organic matter improves the soil water holding capacity, making plants able to withstand short periods of droughts (Rice, 2002). Hence, sewage sludge has the potential to be used as an effective soil amendment, even having the potential of replacing the need for organic fertilizers.

\subsection{Growth Performance and Plant Biomass}

The highest total height of the D.verrucosus plant $(67.27 \mathrm{~cm})$ was recorded in the T1. Besides that, the D.verrucosus plant in the $\mathrm{T} 1$ growth media also produced the highest number of leaves (33). The basal diameter was found to be constant after 8 weeks of planting; although the $\mathrm{T} 1$ and $\mathrm{T} 2$ were found to have slightly higher basal diameter. This shows that the D.verrucosus plant showed normal growth in terms of basal diameter (Majid et al., 2011). However, the D.verrucosus plant in treatment 5 exhibited the lowest basal diameter $(5.5 \mathrm{~cm})$. Furthermore, the D.verrucosus plant in treatment 5 also recorded the lowest number of leaves (7). These results indicate that to attain the optimum growth of the D.verrucosus plant, the ideal composition of the growth media should be $20 \%$ sewage sludge and $80 \%$ soil. This is most likely due to sufficient organic matter contribution by the sewage sludge without severely increasing the $\mathrm{pH}$ of the soil (Parisa et al., 2010) content. The T5 growth media exhibited the worst growth performance, indicating that a $100 \%$ sewage sludge growth media would be the least ideal growth media for the D.verrucosus plant, maybe due to higher acidity and heavy metal content (Mangkoedihardjo and Surahmaida, 2008). After 16 weeks, treatment 5 produced the lowest biomass of $23.65 \mathrm{~g}$ and $14.46 \mathrm{~g}$ for stem and leaves, respectively. This is a clear indication that the D.verrucosus plant is unable to grow optimally in soil with very high amounts of sewage sludge. Treatment 2 produced the highest biomass of $51.38 \mathrm{~g}, 53.28 \mathrm{~g}$ and $57.86 \mathrm{~g}$ for roots, stem and leaves. The plant biomass plays an important role in the absorption of heavy metal from soil and water (Majid et al., 2011). Plant which is used as a phytoremediator must have both high potential capacity to absorb elements from soil or water and large biomass. Treatment 2 with the combination of $60 \%$ soil and $40 \%$ sludge produced the highest biomass, indicating that this plant can be used for remediation of sludge contaminated soils (Majid et al., 2011).

\subsection{Heavy Metal Concentrations in Plant Parts}

The highest accumulation of $\mathrm{Zn}(68.47 \mathrm{ppm})$ in D.verrucosus was recorded in the stem at $\mathrm{T} 5$ growth media. In all treatments, the $\mathrm{Zn}$ accumulation is highest in the stem compared to the leaves and roots. Since the 
D.verrucosus plant in the T5 growth media exhibited the worst growth performance, it indicates that $\mathrm{Zn}$ toxicity in plants limited the growth of the plant (Fontes and Cox, 1998). Besides that, excess $\mathrm{Zn}$ has been found to cause manganese and copper deficiencies (Ebbs and Kochian, 1997). The stem of the D.verrucosus in T3 recorded the highest $\mathrm{Cd}$ accumulation (2.85 ppm), followed by the leaves of the D.verrucosus in T3 $(2.7 \mathrm{ppm})$. This is because cadmium is a mobile heavy metal, easily transported from the root of the plant to the stem and leaves. The roots of the D.verrucosus were found to absorb high levels of $\mathrm{Fe}$ compared to the stem and leaves. The highest accumulation of $\mathrm{Fe}$ was recorded in the roots of the D.verrucosus in T5 (1879.75 ppm). The highest $\mathrm{Pb}$ uptake was recorded in the roots of D.verrucosus in T5 (37.3 ppm), followed by the roots of the D.verrucosus in T4 (36.93 ppm), while the lowest accumulation of $\mathrm{Pb}$ was noted in the stem of the D.verrucosus in control (23.49 ppm). The roots of the D.verrucosus in $\mathrm{T} 5$ had the highest uptake of $\mathrm{Cu}(8.23$ $\mathrm{ppm})$. The lowest $\mathrm{Cu}$ uptake was recorded in the stem of the D.verrucosus in the Control (4.03 ppm). Lower levels of $\mathrm{Pb}$ and $\mathrm{Cu}$ in the stem compared to the roots of the D.verrucosus plant was due to $\mathrm{Pb}$ and $\mathrm{Cu}$ being less mobile heavy metals.

\subsection{Relationship between Heavy Metal Concentrations in the Growth Media and the Accumulation of Heavy Metal in Plant Parts}

The highest concentration of $\mathrm{Fe}, \mathrm{Zn}, \mathrm{Cu}$ and $\mathrm{Pb}$ in all plant parts (roots, leaves and stem) of the D.verrucosus plant was recorded in the T5 growth media. This shows that the higher the concentration of $\mathrm{Fe}, \mathrm{Zn}, \mathrm{Cu}$ and $\mathrm{Pb}$ in the growth media, the higher the uptake of the heavy metals by the D.verrucosus plant. This increase in accumulation of heavy metal negatively affected the growth performance of the plant (Arifin et al., 2011). The uptake of $\mathrm{Cd}$ by the D.verrucosus plant was highest in $\mathrm{T} 3$ indicating that the D.verrucosus plant was unable to uptake $\mathrm{Cd}$ when there are high concentrations of $\mathrm{Cd}$ present in the soil (Majid et al., 2011). This indicates that the D.verrucosus plant is only able to uptake $\mathrm{Cd}$ at an optimum level when the $\mathrm{Cd}$ concentration of the growth media is not higher than $4 \mathrm{ppm}$. The highest concentration of heavy metal in the roots of the D.verrucosus plant in the T5 growth media was Fe (1879.75 ppm), followed by $\mathrm{Zn}$ (23.46 ppm), while the minimum was $\mathrm{Cd}$ (1.05 ppm). This shows that the roots of the D.verrucosus plant are most efficient in uptaking and storing Fe. Despite Fe being highly insoluble, the presence of organic ligands can convert $\mathrm{Fe}$ to be in a mobile form; hence the high uptakes of $\mathrm{Fe}$ by the roots of the D.verrucosus plant (Perk, 2013). The stem of the D.verrucosus plant was also found to be highly efficient in storing $\mathrm{Zn}$.

\subsection{Differences in Translocation Factor (TF) and Bioconcentration Factor (BCF) among Treatments and Heavy Metals}

The TF for iron was the lowest among all other TF (0.19 in treatment 1$)$, while it's BCF was highest among all other BCF (2.67 in Treatment 1). This is due to the D.verrucosus plant storing almost its entire Fe uptake in its roots (Yoon et al., 2006). Low TF and high BCF shows that the D.verrucosus plant is not suitable to be used as phytoextractor for iron (Majid et al., 2011), as ideal phytoremediator plants should store heavy metals in its stem. However, the TF for $\mathrm{Cd}, \mathrm{Zn}, \mathrm{Cu}$ and $\mathrm{Pb}$ was above 1 while its $\mathrm{BCF}$ was low, indicating that the D.verrucosus plant could be a good phytoextractor of $\mathrm{Cd}, \mathrm{Zn}, \mathrm{Cu}$ and $\mathrm{Pb}$. (Baker, 1981).

\section{CONCLUSION}

The D.verrucosus plant was found to be suitable for taking up heavy metals from soil contaminated with sewage sludge. This is especially true for $\mathrm{Zn}$ and $\mathrm{Cd}$ since the plant stores the heavy metals in its stem, which are removed from the soil when the plant is harvested for getting its resin. Fe was also stored in the D.verrucosus plant, but mainly in the roots. The potential of D.verrucosus plant to be used as a phytoextractor for $\mathrm{Fe}$ is unfavourable, indicated by its low TF and high BCF. Based on the TF and BCF values, the D.verrucosus can be recommended to be used as a phytoremediator, especially for $\mathrm{Cd}, \mathrm{Zn}, \mathrm{Cu}$ and $\mathrm{Pb}$. Primarily, the duration of the study needs to be extended and the effectiveness of the D.verrucosus plant in accumulating heavy metals in an open environment needs to be also conducted. The D.verrucosus plant has the potential to be a phytoremediator plant but needs to be further evaluated to optimize its potential.

\section{ACKNOWLEDGEMENT}

We are thankful to the Ministry of Higher Education, Malaysia (MOHE) through Fundamental Research Grant Scheme (FRGS) and Universiti Putra 
Malaysia, Malaysia (UPM) for the financial and technical support.

\section{REFERENCES}

Arifin, A., A. Najihah, A.H. Hazandy, J. Shamshuddin and S.K. Daljit et al., 2011. Using Orthosiphon stamineus $B$. for Phytoremediation of Heavy metals in soils amended with sewage sludge. Am. J. Applied Sci., 8: 323-331. DOI: 10.3844/ajassp.2011.323.331

Baker, A.J.M., 1981. Accumulators and excludersstrategies in the response of plants to heavy metals. J. Plant Nutr., 3: 643-654. DOI: 10.1080/01904168109362867

Bennett, L.E., J.L. Burkhead, K.L. Hale, N. Terry and M. Pilon et al., 2003. Analysis of transgenic Indian mustard plants for phytoremediation of metal contaminated mine tailings. J. Environ. Q., 32: 432-440. PMID: 12708665

Ebbs, S.D. and L.V. Kochian, 1997. Toxicity of zinc and copper to Brassica species: Implications for phytoremediation. J. Environ. Q., 26: 776-781. DOI: 10.2134/jeq1997.00472425002600030026x

Fontes, R.L.S. and F.R. Cox, 1998. Zinc toxicity in soybean grown at high iron concentration in nutrient solution. J. Plant Nutr., 21: 1723-1730. DOI: 10.1080/01904169809365517

Ghafoori, M., M. Nik Majid, M.M. Islam and S. Luhat, 2011. Bioaccumulation of heavy metals by Dyera costulata cultivated in sewage sludge contaminated soil. Afr. J. Biotechnol., 10: 10674-10682.

Indah Water Konsortium (IWK), 1997. Sewage Treatment Plant.

Kvesitadze, G., G. Khatisashvili, T. Sadunishvili and J.J. Ramsden, 2010. Biochemical Mechanisms of Detoxification in Higher Plants: Basis of Phytoremediation. 1st Edn., Springer, New York, ISBN-10: 3642067026, pp: 266.

Majid, N.M., M.M. Islam, J. Veronica, A. Arifin and A. Parisa, 2011. Evaluation of heavy metal uptake and translocation by Acacia mangium as a phytoremediator of copper contaminated soil. Afr. J. Biotechnol., 10: 8373-8379.

Mangkoedihardjo, S. and S. Surahmaida, 2008. Jatropha curcas $L$. for phytoremediation of lead and cadmium polluted soil. World Applied Sci. J., 4: 519-522.
Muhtadi, 2008. Fitokimia beberapa spesies Dipterocarpaceae Indonesia dari genus Dipterocarpus. Published Doctoral Dissertation, Central Library Institute Technology Bandung.

Odegaard, H., B. Paulsrud and I. Karlsson, 2002. Wastewater sludge as a resource: Sludge disposal strategies and corresponding treatment technologies aimed at sustainable handling of wastewater sludge. Water Sci. Technol., 46: 295-303. PMID: 12479484

Parisa, A., M.N. Azmi, A. Arifin, A.H. Hazandy and K.S. Daljit et al., 2010. Uptake of heavy metals by Jatropha curcas L. planted in soils containing sewage sludge. Am. J. Applied Sci., 7: 1291-1299. DOI: 10.3844/ajassp.2010.1291.1299

Perk, M.V.D., 2013. Soil and Water Contamination: From Molecular to Catchment Scale. 2nd Edn., Taylor and Francis Group, New York, ISBN-10: 0415893437, pp: 450.

Purakayastha, T.J. and P.K. Chhonkar, 2010. Phytoremediation of Heavy Metal Contaminatrd soils. In: Soil Heavy Metals, Sherameti, A.V.I., (Eds.), New York, Springer, ISBN-10: 364202436X, pp: 397-398.

Raymond, A.W. and E.O. Felix, 2011. Heavy metals in contaminated soils: A Review of Sources, Chemistry, Risks and Best Available Strategies for Remediation. ISRN Ecol., 2011: 20-61.

Reeves, R.D. and A.J.M. Baker, 2000. Metal accumulating plants. In: Phytoremediation of Toxic Metals: Using Plants to Clean Up the Environment, Raskin, I. and B.D. Ensley, (Eds.), Wiley, New York, ISBN-10: 0471192546, pp: 193-229.

Rice, C.W., 2002. Storing carbon in soil: Why and how? American Geological Institute.

Singh, R.P. and M. Argawal, 2007. Potential benefits and risks of land application of sewage sludge. Waste Manage., 28: 347-358. $\quad$ DOI: 10.1016/j.wasman.2006.12.010

Yoon, J., X.D. Cao, Q.X. Zhou and L.Q. Ma, 2006. Accumulation of $\mathrm{Pb}, \mathrm{Cu}$ and $\mathrm{Zn}$ in native plants growing on a contaminated Florida site. Sci. Total Environ., 368: 456-464. $\quad$ DOI: 10.1016/j.scitotenv.2006.01.016

Zuraida, W. and W.M. Zain, 2011. The evaluation of antioxidant, antibacterial and structural identification activity of trimer resveratrol from Malaysia's dipterocarpaceae. Aus. J. Basic Applied Sci., 5: 926-929. 